\title{
Russian Official Reflection in Russian Language Winged Units
}

\author{
Svetlana Anokhina ${ }^{1}$, Natalia Kozko $^{2}$, Natalia Pozdnyakova ${ }^{3}$ and Ekaterina Tulina ${ }^{4}$ \\ ${ }^{1}$ Nosov Magnitogorsk State Technical University, Russia
}

\begin{abstract}
The article analyzes functioning of winged units nominating officials in literary and publicistic texts included in the Russian National Corpus. The authors consider that every winged phrase is a combination of mental ideas of the nation. Thus, winged units are important concepts verbalisators though they are found at the semantic field periphery. The article brings out the differences in the usage of winged units with the common seme "official" in texts by native Russian speakers which allows to reconstruct the image of an official existing in the Russian linguistic picture of the world. Most units can be found at the periphery of the semantic field and thus cannot claim to be universal in nominating officials because of low frequency of their use. The most universal nominations for officials are the following ones: Derzhimorda, Kuvshinnoe rylo, Schvonder, Sergeant Prishibeyev, Akaky Akakievich Bashmachkin, that can be related to the near periphery of the concept "Official" field verbalisators. The analysis of winged units' meanings with the seme "official" allows specifying ideas of an official in the Russian linguistic picture of the world: the majority of the winged units convey a negative attitude of native speakers to officials.
\end{abstract}

\section{Introduction}

Winged units (hereafter WUs) of the Russian language are important concepts' verbalisators though they are at the semantic field periphery. According to S. Shulezkova in WUs, "the lively Russian mind is reflected like in memory fragments of many generations; and the Russian soul loves, languishes, suffers, judges, warns and laughs" [1]. Every WU includes not only its origin, its meaning but also a wide range of the people's ideas. "Due to the natural speakers' knowledge of culture and the analysis of dynamic processes in the social and political sphere, language indicators of culture try to "suit", to interpret or understand the data for the discourse appropriately" [2].

This paper analyzes WUs with the seme "official" ("administrator", "bureaucrat", "careerist", "chief", "manager", "penpusher"), functioning in different literary works written in Russian. The source of the material for the analysis is the Russian National Corpus (hereafter RNC) that "represents the language at a particular stage (or stages) of its existence in its diversity of genres, styles, territorial and social versions" [3]. National corpuses give a rich material for numerous linguistic researches in different spheres [4-6] and others.

Table 1. WUs with the seme "official" usage statistics in RNC.

\begin{tabular}{|l|c|c|c|c|}
\hline $\begin{array}{l}\text { The search } \\
\text { query }\end{array}$ & $\begin{array}{c}\text { The } \\
\text { numbe } \\
\mathrm{r} \text { of } \\
\text { texts }\end{array}$ & $\begin{array}{c}\text { The } \\
\text { numbe } \\
\mathrm{r} \text { of } \\
\text { times } \\
\text { used }\end{array}$ & $\begin{array}{c}\text { The } \\
\text { text } \\
\text { dating }\end{array}$ & $\begin{array}{c}\text { Meaning of WUs } \\
\text { according to } \\
\text { "Dictionary of } \\
\text { Winged Words of } \\
\text { the Russian } \\
\text { Language" [7] }\end{array}$ \\
\hline
\end{tabular}

\begin{tabular}{|c|c|c|c|c|}
\hline $\begin{array}{l}\text { Akaky } \\
\text { Akakievich } \\
\text { Bashmachkin }\end{array}$ & $82 / 32$ & $\begin{array}{c}270 / \\
80\end{array}$ & $\begin{array}{l}1842- \\
2004\end{array}$ & $\begin{array}{l}\text { Literary or old- } \\
\text { fashioned. } \\
\text { expression was used } \\
\text { to characterize } \\
\text { downtrodden, fate } \\
\text { obedient petty } \\
\text { officials of imperial } \\
\text { Russia }\end{array}$ \\
\hline Molchalin & 79 & 396 & $\begin{array}{l}1839- \\
2010\end{array}$ & $\begin{array}{l}\text { It was used to } \\
\text { describe } \\
\text { obsequious careerist, } \\
\text { a penpusher. }\end{array}$ \\
\hline Derzhimorda & 67 & 145 & $\begin{array}{l}1836- \\
2011\end{array}$ & $\begin{array}{lr}\text { Disapproving. It is } \\
\text { used to describe a } \\
\text { self-willed and rude } \\
\text { manager who treats } \\
\text { people r with } \\
\text { insolence, mostly } \\
\text { used to describe } \\
\text { officials } \\
\text { managers. }\end{array}$ \\
\hline $\begin{array}{l}\text { Kuvshinnoe } \\
\text { rylo }\end{array}$ & 25 & 36 & $\begin{array}{c}1842- \\
2007 \\
\end{array}$ & $\begin{array}{l}\text { Used to speak about } \\
\text { officials on the take. }\end{array}$ \\
\hline $\begin{array}{l}\text { Sergeant } \\
\text { Prishibeyev }\end{array}$ & 21 & 39 & $\begin{array}{l}1885- \\
2002\end{array}$ & $\begin{array}{l}\text { A petty tyrant } \\
\text { imposing his will on } \\
\text { everybody, putting } \\
\text { an end to any } \\
\text { attempts to act freely } \\
\text { and independently }\end{array}$ \\
\hline $\begin{array}{l}\text { Arhivnye } \\
\text { yunoshi }\end{array}$ & 15 & 23 & $\begin{array}{l}1858- \\
2007\end{array}$ & $\begin{array}{l}\text { It is used to speak } \\
\text { about young } \\
\text { officials of the } \\
\text { beginning of the } \\
\text { previous century } \\
\text { having certain } \\
\text { privileges. }\end{array}$ \\
\hline
\end{tabular}

\footnotetext{
*Corresponding author: asa.06@inbox.ru
} 


\begin{tabular}{|l|c|c|c|l|}
\hline Schwonder & 12 & 57 & $\begin{array}{l}1925- \\
2004\end{array}$ & $\begin{array}{l}\text { A rude, cheeky, } \\
\text { unscrupulous } \\
\text { bureaucrat }\end{array}$ \\
\hline $\begin{array}{l}\text { Prozasedavs } \\
\text { hiesya }\end{array}$ & 7 & 7 & $\begin{array}{l}1964- \\
2007\end{array}$ & $\begin{array}{l}\text { It is used to describe } \\
\text { people who prefer } \\
\text { endless debate at } \\
\text { meetings to practical } \\
\text { work. It is a } \\
\text { figurative } \\
\text { characteristic of } \\
\text { officials-bureaucrats. }\end{array}$ \\
\hline $\begin{array}{l}\text { Ugryum- } \\
\text { Burcheev }\end{array}$ & 6 & 34 & $1869-$ & $\begin{array}{l}\text { Used to describe the } \\
\text { administrator who is } \\
\text { a petty tyrant and a } \\
\text { stupid person }\end{array}$ \\
\hline
\end{tabular}

The table represents the analyzed units in a descending order according to the number of texts where they are mentioned. The first line combines the results of two search queries as they deal with the name of one character and one WU. There is no ground to summarize these results as in most contexts the name, the patronymic and the surname of Gogol's characters are used simultaneously. It is worth noting that if we take the number of mentions of the unit in RNC as the basis of the rating, the rating will be a little bit different, but the main trends will remain the same.

All analyzed in this article WUs go back to works of Russian literature, connection with which in most cases determines peculiarities of WUs functioning. As for the analyzed nominations of officials, this connection with the source becomes obvious when conducting a comparative analysis of contexts of these units usage. All of them - Akakys Akakievich, arhivnye yunoshi, Derzhimordas, Kuvshinnoe rylos, Molchalins, Prozasedavshiesya, Ugryum-Burcheevs, Sergeants Prishibeyev, Schvonders are officials but they differ not only in their personality, behavior and attitude to work (which found reflection in vocabulary definitions of WUs) but also in the sphere of activities.

\section{Winged Units Being the Verbalisators of the Concept "Official" in Russian Linguistic Picture of the World}

The analysis of WUs meanings with the seme "official" allows to get an idea about significant from the native Russian speakers' point of view qualities of officials as "studying any linguistic cultural concept being a unit of any linguistic picture of the world is valuable for culture as it allows to reveal cultural and world-view peculiarities of a particular linguistic and cultural community" [8]. Meanings of the most mentioned WUs reveal a negative attitude of native speakers to officials. This attitude is marked with the help of the note disapproving and using in definitions negative characteristics of an official: downtrodden, fate obedient, obsequious on the one hand and self-willed, rude, treating others with insolence, bribetaker, numskull, petty tyrant, rude, cheeky, unscrupulous - on the other. Just a simple enumeration of characteristics of officials called with the help of WUs depicts unattractive images. In this group only WU arhivnye yunoshi has a neutral meaning.

It is remarkable that the meanings of most analyzed units are linked with officials in general without any reference to these WUs origin time and the lifetime of so-called officials. It confirms the conclusions that the negative ideas of the Russian people about officials are proof against years [9]

The analysis of WUs usage with the seme "official" in texts created by Russian native speakers gives a lot of information to create an image of an official existing in the Russian linguistic picture of the world, provides "relevant evaluation categories, at the basis of which there are criteria for evaluation connected with an employee's qualification, complexity and intensity of work, quality of work, an employee's zeal (responsibility)" [10]. However, not all the mentioned above WUs play a huge role in the concept "Official" verbalization. The frequency of their use in the texts of RNC (table 1) gives rather interesting information to ponder on what characteristics of the described officials are becoming the most popular with contemporary writers. But when comparing the frequency of WUs use we must take into consideration that the search query in RNC gives contexts of the analyzed units use without considering all their meanings, in other words, not in all cases we deal with WUs. That's why arhivnye yunoshi, Molchalin, Ugryum-Burcheev, prozasedavshiesya were referred to the far periphery of the concept field verbalisators because of low frequency of their use as WUs with the seme "official".

Judging by the number of texts where it can be found, the least frequent is the surname of the city governor Ugryum-Burcheev from "The History of a Town” by M.E. Saltykov-Shchedrin. We haven't found this WU used in the necessary meaning in RNC.

As for the word prozasedavshiesya, among its examples there is only one context where it is used as a WU: I had a dream that my name was called at some discussion at the State Duma as if I had a bank account in another country as if it were very bad and more than that I was somebody's woman, and not just somebody's but ... To listen to it in Russia through a loudspeaker is as funny and absurd as not to hear it in America where any simple adultery leads to a divorce and non-payment taxes to prison. I was standing with a raised head downstairs in the foyer where all prozasedavshiesya came to have a smoke and gossip and couldn't believe my ears (K. Surikova, «Bye-bye, love, bye-bye, happiness!..», 2003). In other six texts, the authors mention the poem with the same title by $\mathrm{V}$. Mayakovsky.

The contexts of the WU arhivnye yunoshi use in most cases reflect its reference to young philosophizing noble officials of the beginning of the $19^{\text {th }}$ century: It was located in Pirogovskaya Street near Deviche Pole and it seemed to me that in that building "arhivnye yunoshi" of Pushkin's time served, and Alexander Ivanovich Turgenev exactly here spoilt his eyesight having ruined it by his constant search for documents on the history of 
Russia in all archives of Europe (E. Gershtein "Unnecessary Love", 1985-2002).

However, it should be noted that there is a tendency to widen WU meaning and to include their denotations of archive clerks and civil servants, even present-day ones. "I wonder whether it is interesting and amusing for readers, unless they are arhivnye yunoshi, to read, or is it fun for me, unless I'm not filling in the questionnaire, to write about something that could be interesting only for the owner. (A. Naiman. "The Glorious End of Inglorious Generation", 1994). In this case WU is used in a more general meaning than a definition given in the dictionary. Nevertheless, its single use doesn't allow us to speak about the true widening of WU arhivnye yunoshi meaning. In general WU preserves its status "humorous name of a group of young noble men indulging in philosophizing who served in the Moscow archive of the State Collegium of Foreign Affairs in the 1920s [XIX - S.A.] [7].

The frequency of WU use which names civil servants in different texts of RNC in comparison with the meaning of these units (Table 1) gives rather interesting food for thought about the qualities and features of the described civil servants that are currently topical among contemporary writers. One of the most frequently used references in RNC from the units mentioned above is Molchalin, the surname of the main character from the comedy "Woe from Wit" by A. Griboyedov. It can be counted 396 times in 79 documents in a period from 1839 to 2011, but in most cases this unit is used by the authors as a surname of the main character, not as WU. But even if they use it as WU, in the first place they mean not the profession, but the traits of character of a person, named Molchalin: and Sasha has a psychology of an excellent student, in his poetry he is Molchalin, diligent, sensible, punctual; everything is thought out to the last detail - everyone loves him, everyone publishes him; he has only one unpublished poem, he has earned recognition and fame; everyone regards his opinion and still there is a feeling of failure, that something has been done wrong or hasn't been done at all, but he has been trying to get it, has been planning it, has been inventing some power transmitting chain that doesn't work, it hasn't made a contact, the control lamp doesn't shine, and it's not clear what the matter is. That's why he is gloomy; the wrinkle on his mouth somehow gives out everything - not a tragedy, but some dissatisfaction (V. Solovyov "Three Jews or Consolation in Tears, a Novel with Epigraphs", 1975-1998). It is obvious that "moderation and accuracy" are characteristic not only of officials, but also of an officer, a poet, a person of any profession and these qualities are basic in nominating these people Molchalin. Thus, we can conclude that in the texts of RNC officials are given the name Molchalin.

But the name of a policeman from the comedy "The Inspector General" by N.V. Gogol Derzhimorda can be found in the texts of RNC more rarely than Molchalin (145 times in 67 documents in the period from 1836 to 2011), however, in the vast majority of concepts it functions as a winged nomination of officials: "However, all of us working in Soviet art and literature have gone through gigantic school dealing with amendments and comments. We've been given guidelines and carried out different instructions from the government and the leading Derzhimordas (E. Ryazanov "Summary", 2000). It allows us to relate WU Derzhimorda as well as Kuvshinnoe rylo, Schvonder Sergeant Prishibeev and Akaky Akakievich Bashmachkin to the near periphery of the concept "Official" field verbalisators. Different concepts where these WUs are used illustrate certain trends in nominating officials.

In this case WU Schvonder is used by authors mainly in connection with a "housing problem". As you know, the character of the novel "Heart of a dog" by M. Bulgakov, being a chairman of the house committee, is concerned about the fact that Professor Preobrazhensky "occupies excessive housing area". The case of the Bulgakov bureaucrat did not fall into oblivion, but was continued by modern Schvonders, there is no shortage of them nowadays: "Though I am a Candidate of Science, my husband is a Professor and we have a right to occupy some additional housing area, there appear some new "Schvonders" and "Sharikovs" who launch a campaign against Sobchak" (L. Narusova, A. Nitochkina "I'm Afraid of Jinxing...”, 1991).

Sergeant Prishibeev, being a WU in all contexts of its functioning in RNC, does not fall out of touch with security services, because the character of the eponymously-named short novel by A. Chekhov, a retired sergeant considered himself to be a guardian of the law and interfered in other people's affairs in a blunt manner and told them what to do. Solutions to the problem or a conflict by force typical for the army are transferred to other spheres where there are modern sergeants Prishibeevs. In this regard, Prishibeev and Derzhimorda are closely related and used by the authors in pair: "Oh, no.... no. The process cannot be stoppedRussia is using a European model of development now, sir, all these snoopers, Prishibeevs, Derzhimordas, executioners and other offsprings of age-old slavery will gradually die out (V. Aksenov "Love for Electricity", 1969).

Akaky Akakievich Bashmachkin has settled down in the lower steps of the career ladder. The analysis of this WU in RNC suggests that this WU hasn't lost its relevance in the XX-XXI centuries. This Gogol character is brought back to memory when we talk about officials having no prospects for promotion and career growth: Novoseltsev is a humble and unremarkable office worker who got stuck in the position of a senior statistician, despite years of honorable service. It is a kind of modern Akaky Akakievich. He is considered by Kalugina as an ordinary and lacking initiative worker whose family life has also ended in fiasco (E. Ryazanov "Summary", 2000).

What kind of officials named by means of WUs can count on promotion and career growth? Judging by data from RNC these are Kuvshinnoe rylo, and Derzhimorda. Texts written in the XX century give some interesting material for the analysis of WU Kuvshinnoe rylo which nominates Officials and reflects the change in the attitude to officials in general and to the disgusting face of the governorship and authority in particular. At the beginning of the century, Kuvshinnoe rylo is an ordinary 
Official who has not achieved promotion at work: "Then the service started at 90 'clock in the morning and it was still dark outside at this time in winter in St. Petersburg. Officials ran to work in frosty weather, burying their noses in knitted scarves and lifting collars of their overcoats. Their service caps with badges were padded and even with earflaps, they were carrying worn-out leather briefcases under their arms. These were Akakys Akakievich, Kuvshinnoe rylos, Yaichnicas and Podkolyosins (P.P. Gredich "Book of Life", 1918). At the end of the XX century, Kuvshinnoe rylo climbs up to the top of the bureaucratic hierarchy: "I said that all these Kuvshinnoe rylos standing in a line on the rostrum of the Mausoleum would soon be wiped out or replaced (I've also thought about a 5-year-plan) by others with a more manlike appearance (V. Voinivich "The Design", 1999). Kuvshinnoe rylos have not only worked towards promotion, they are governing the state, but still do not have any peculiar features - another author at a different time characterizes them as completely identical official old men. Kuvshinnoe rylo has grown up from those smart and tough-minded boys about whom $\mathrm{K}$. Chukovsky writes: "You are a little squirrel! You've got nice little paws!" But he got angry and objected to it: "I'm not a squirrel, I'm Lyeva, I've got no paws, but hands." Of course, we can't expect him to become a Mendeleev, he can probably become a Kuvshinnoe rylo. Fortunately, such disabled people are rare. (K. Chukovsky "From 2 to 5"). A child without imagination is a disabled person who, according to the author, may become an official, even an official of the top ranking.

From the point of view of career growth, Derzhimorda is a universal type of an official. Probably, features of a policeman from the comedy "The Inspector General" by N.V. Gogol, who can easily "give a black eye both to those who are right and who are at fault" (N.V. Gogol "The Inspector General") are the most suitable for the Russian bureaucratic reality: A party directive is issued from the Moscow Derzhimordas and going down to the basic organization is subjected to being processed by regional authorities, local Derzhimordas who try to adjust the directive to local conditions. So, one and the same directive, born in Moscow, going to a village or a plant, turns into a multiheaded hydra. Regional Derzhimordas don't consult each other about this directive. When a directive ends with another collapse, there appears a fierce interdepartmental fight. Dig Derzhimordas cast the blame onto small Derzhimordas. And our most active members go to the Urals to do some under work or to the concentration camp (I.L. Solonevich "Russia in a Concentration Camp", 1935). Derzhimorda can be found at any level of service hierarchy, in any settlement (a town or a village), at any work field.

For the sake of justice, we should note that according to the authors whose texts are included in RNC, Derzhimorda is universal not only in the Soviet table of ranks, but knows no time or geographical bounds:'The first one out of the true believers of Nicolas II who tried to murder him was the city governor of Yalta, known as Black-Hundreder type of Derzhimorda General Dumbadze (N. N. Evreinov "The Mystery of Rasputin",
1924). Sturdy Truman Derzhimordas trussed up the hands of a small Japanese girl who pasted up ads and leaflets calling for peace (B.E. Efimov. "Drawings of the Artist B. Prokofov. For peace”, 1952).

The proof that corruption among officials is a widespread phenomenon can be found in works of other researchers: "Corruption strikes observes with its universal character. From the point of view of a person, corruption is expressed in the following sentence: "Everyone is a bribe-taker; everything depends only on the sum of the bribe!" It means that corrupt potential motivates each of us; nobody can feel safe from it. Corruption is omnipotent. Bribes are often considered to be the correct key to open any door. From the point of view of society, the universal character of corruption is manifested in its ubiquity. It happens on all continents, in all types of governmental institutions and political funds, in all spheres of public administration throughout all periods of the human civilization development [11].

\section{Conclusion}

Having analyzed the functioning of WUs that verbalize the concept "Official", we can draw the following conclusions. Most WUs cannot be considered universal in nomination of Officials. So, arhivnye yunoshi, Molchalin, Ugryum-Burcheevs, Prozasedavshiesya are referred to the far periphery of the concept field verbalisators due to the low frequency of their use as WUs with the seme "Official". Other WUs are used to characterize officials of a certain work field of a certain position in the service hierarchy (Schvonder, Sergeant Prishibeev, Akaky Akakievich Bashmachkin). However, the most universal symbol of the Official among all the WUs is Derzhimorda. With the help of this unit, the authors characterize an official of different levels having the same desire to overcome difficulties from the position of strength. However, this WU with the meaning "Official" is the most frequently used. It allows us to relate WU Derzhimorda to the near periphery of the concept "Official" field verbalisators, as well as such WUs as Kuvshinnoe rylo, Schvonder, Sergeant Prishibeev, Akaky Bashmachkin). According to the analysis, only Derzhimorda and Kuvshinnoe rylo, although they are disgusting and unpleasant both to the author and to the readers, can count on career promotion. These WUs are associated with the harsh naming of a person's face and it proves the idea of a Russian about an Official. It is sad to admit that in the mirror of Russian WUs, we can see the most abominable snouts and muzzles of the officials.

\section{References}

1. S.G. Shulezhkova, Winged Units of the Russian Language, their Origin and Development (“Azbukovnik", Moscow, 2002)

2. N. Demjanova, Search for Equivalence IV, 348355. (Prešov, 2009) 
3. Russian National Corpus, URL: http://www.ruscorpora.ru// (date of access: 16.04.18)

4. V.A. Plungyan, The Russian Language in Scientific Coverage 2, 7-20 (2008)

5. L.D. Ponomareva, L.N. Churilina, D.S. Buzhinskaya, E.N. Derevskova, O.V. Dorfman, E.P. Sokolova, International Journal of Environmental and Science Education, 8 (11), 13043-13053 (2016)

6. V.E. Chernyavskaya, Issues of Cognitive Linguistics, 2 (55), 31-37 (2018)

7. V.P. Berkov, V.M. Mokienko, S.G. Shulezhkova, Dictionary of Winged Words of the Russian Language: about. 4000 entries, («Russian Dictionaries», «Publishing House Astrel», «Publishing House AST», Moscow, 2000)

8. N.A. Kozko, Issues of History, Philology, Culture, 1, 256-262 (2013)

9. S.A. Anokhina, Issues of History, Philology, Culture 3, 100-102 (2014)

10. E.I. Golovanova, O.N. Kovaleva, Issues of Cognitive Linguistics, 3 (52), 31-36 (2017)

11. M. Chizhmarik, Human and Company, 1 (2005), URL: $\quad$ http://www.saske.sk/cas/archiv/12005/index.html (date of access: 26.04.18) 